\title{
LATIN AMERICAN ECONOMIC SYSTEM (SELA)
}

Established in 1975 by the Panama Convention, SELA (Sistema Económico Latinoamericano) promotes co-ordination on economic issues and social development among the countries of Latin America and the Caribbean.

Members. Argentina, Bahamas, Barbados, Belize, Bolivia, Brazil, Chile, Colombia, Costa Rica, Cuba, Dominican Republic, Ecuador, El Salvador, Grenada, Guatemala, Guyana, Haiti, Honduras, Jamaica, Mexico, Nicaragua, Panama, Paraguay, Peru, Suriname, Trinidad and Tobago, Uruguay, Venezuela.

Official languages. English, French, Portuguese, Spanish.

Headquarters: Apartado 17035, Caracas 1010-4, Venezuela.

Website: http://www.sela.org

e-mail: difusion@sela.org

Permanent Secretary: Roberto Guarnieri (Venezuela).

Publications. Capitulos (in Spanish and English, published thrice yearly); SELA Antenna in the United States (quarterly bulletin); Integration Bulletin on Latin America and the Caribbean (monthly).

\section{LATIN AMERICAN RESERVE FUND}

Established in 1991 as successor to the Andean Reserve Fund, the Latin American Reserve Fund assists in correcting payment imbalances through loans with terms of up to four years and guarantees extended to members, to co-ordinate their monetary, exchange and financial policies and to promote the liberalization of trade and payments in the Andean sub-region.

Members: Bolivia, Colombia, Costa Rica, Ecuador, Peru, Venezuela.

Official language. Spanish.

Headquarters: Edificio Banco de Occidente, Carrera 13, No. 27-47, Piso 10, Santafe de Bogota, DC, Colombia.

Website: http://www.flar.net

Executive President: Julio Velarde (Peru).

\section{THE ANDEAN COMMUNITY}

On 26 May 1969 an agreement was signed by Bolivia, Chile, Colombia, Ecuador and Peru establishing the Cartagena Agreement (also referred to as the Andean Pact or the Andean Group). Chile withdrew from the Group in 1976. Venezuela, which was initially actively involved, did not sign the agreement until 1973. In 1997 Peru announced its withdrawal for five years.

The Andean Free Trade Area came into effect on 1 Feb. 1993 as the first step towards the creation of a common market. Bolivia, Colombia, Ecuador and Venezuela have fully liberalized the trade among them, while Peru is still implementing its liberalization process, due to end by 2005. A Common External Tariff for imports from third countries has been in effect since 1 Feb. 1995.

In March 1996 at the Group's 8th summit in Trujillo in Peru, member countries (Bolivia, Colombia, Ecuador, Peru, Venezuela) signed a reform protocol to the Agreement, according to which the Group would be superseded by the Andean Community, in order to promote greater economic, commercial and political 